\title{
PERLAKUAN AKUNTANSI ZAKAT DALAM LEMBAGA AMIL ZAKAT
}

\section{ZAKAT ACCOUNTING TREATMENT IN AMIL ZAKAT INSTITUTIONS}

\author{
Norita Citra Yuliarti \\ Universitas Muhamamdiyah Jember \\ Email: norita@unmuhjember.ac.id।
}

\begin{abstract}
ABSTRAK
Tujuan penelitian ini adalah untuk mengkaji metode perlakuan akuntansi zakat dalam lembaga amil zakat apakah sudah menerapkan sistem akuntansi zakat baik dalam laporan keuangannya maupun dalam pelaksanaannya. Data yang diperoleh dalam penelitian ini diperoleh baik melalui wawancara, dokumentasi maupun observasi. Setelah semua data atau informasi yang dibutuhkan dalam penelitian ini terkumpul, kemudian disajikan dan di analisa dengan cara deskriptif-kualitatif. Analisa data yang di lakukan dengan cara membandingkan laporan keuangan yang disajikan Baitul Mall Hidayatullah dengan teori akuntansi lingkungan yang sudah ada.
\end{abstract}

Kata Kunci: akuntansi zakat, BMH, perlakuan akuntansi zakat, laporan keuangan

\begin{abstract}
The purpose of this study is to examine the method of accounting treatment of zakat in amil zalcat institutions whether already apply zakat accounting system both in its financial statements and in its implementation. The data obtained in this study obtained either through interviews, documentation and observation. After all the data or information needed in this study collected, then presented and analyzed in a way descriptive-qualitative. Analysis of data that is done by comparing the financial statements presented Baitul Mall Hidayatullah with environmental accounting theory that already exists.
\end{abstract}

Keywords: accounting for zakat, BMH, zakat accounting treatment, financial statements

\section{PENDAHULUAN}

Zakat adalah ibadah yang mengandung dua dimensi, yaitu dimensi vertikal (hablum minallah) dan dimensi horizontal (hablum minannas). Ibadah zakat apabila ditunaikan dengan baik, akan meningkatkan kualitas keimanan, membersihkan dan mensucikan jiwa, dan mengembangkan serta dapat mendatangkan berkah bagi harta yang dimiliki. Disisi lain zakat merupakan salah satu bentuk ibadah yang mengedepankan nilai-nilai sosial juga membawa pesan ritual dan spiritual (Suma, 2003:55). Jika dikelola dengan baik dan amanah zakat akan mampu meningkatkan kesejahteraan umat, serta sebagai institusi pemerataan ekonomi.

Bahwa kenyataan umat islam kini jauh dari kondisi ideal, adalah akibat belum mampu mengubah apa yang ada pada diri mereka sendiri (QS. Ar-ra'du : 11). Potensipotensi dasar yang dianugerahkan Allah kepada ummat islam belum dikembangkan secara optimal. Padahal ummat memiliki banyak intelektual dan ulama, disamping potensi sumber daya manusia dan ekonomi yang melimpah. Jika seluruh potensi itu dikembangkan secara seksama, dirangkai dengan potensi aqidah islamiyah kaum 
muslimin juga makin meningkat maka pintu-pintu kemungkaran akibat kesulitan ekonomi akan dapat dipersempit.

Salah satu sisi ajaran islam yang belum ditangani secara serius adalah penanggulangan kemiskinan dengan cara mengoptimalkan pengumpulan dan pendayagunaan zakat, infaq, shadaqah, dalam arti seluas-luasnya. Padahal ummat islam (Indonesia) sebenarnya memiliki potensi dana yang sangat besar dengan potensi sumber daya manusia yang melimpah.

Dengan adanya keputusan yang mengatur tentang pengelolaan zakat mewajibkan kepada Lembaga Amil Zakat (LAZ) maupun Badan Amil Zakat (BAZ) untuk membuat Laporan Keuangan dan diaudit secara independen atas laporan keuangannya. Dalam proses pelaporan keuangan BAZ dan LAZ selama ini sampai SK Menteri Agama tersebut dikeluarkan, Organisasi Pengelola Zakat (OPZ) belum memiliki standart akuntansi keuangan sehingga terjadi perbedaan penyusunan laporan keuangan antara satu lembaga dengan lembaga lainnya. Organisasi Pengelola Zakat (OPZ) yang cukup inovatif kemudian menggunakan PSAK No 45 tentang pelaporan keuangan organisasi Nirlaba. Namun demikian, penggunaan PSAK tersebut tidaklah mampu sepenuhnya mengatasi permasalahan standar akuntansi keuangan untuk Organisasi Pengelola Zakat (OPZ). Sampai pada akhir tahun 2005, Forum Zakat berupaya menyusun Pedoman Akuntansi bagi Organisasi Pengelola Zakat (PA-OPZ) (Muhammad, 2008:432). Belum lagi sempat disosialisasikan dan diterapkan secara luas, Forum Zakat telah mengadakan kerja sama dengan Ikatan Akuntan Indonesia untuk menyusun PSAK Zakat pada tahun 2007. Akhirnya pada tahun 2008, IAI telah menyelesaikan ED PSAK No. 109 tentang Akuntansi Zakat .

Instrument yang digunakan sebagai dasar dalam pengambilan keputusan bisnis adalah laporan keuangan. Laporan keuangan dalam suatu organisasi, lembaga atau badan mencerminkan kondisi organisasi saat ini dan dapat digunakan untuk memprediksi keadaan organisasi dimasa mendatang. Selain digunakan sebagai salah satu dasar pengambilan keputusan manajemen, laporan keuangan juga dipakai oleh berbagai pihak yang mempunyai kepentingan terhadap organisasi seperti donatur, calon donatur, pemilik, karyawan, dan lain-lain.

\section{TINJAUAN PUSTAKA}

\section{Pengertian Zakat}

Ditinjau dari segi bahasa kata zakat merupakan kata dasar dari zaka berarti suci, berkah, tumbuh, dan terpuji. Sedangkan dari segi istilah fiqih, zakat berarti sejumlah harta tertentu yang diwajibkan Allah diserahkan kepada orang yang berhak menerimanya, disamping berarti mengeluarkan jumlah tertentu itu sendiri (Qardhawi,1999:34). Menurut etimologi syari'at (istilah), zakat adalah nama bagi sejumlah harta tertentu yang telah mencapai syarat tertentu yang diwajibkan Allah untuk dikeluarkan dan di berikan kepada orang-orang yang berhak menerimanya. Di dalam AlQur'an Allah SWT telah menyebutkan tentang zakat dah shalat sejumlah 82 ayat. Dari sini disimpulkan secara deduktif bahwa zakat merupakan rukun islam terpenting setelah shalat. Zakat dan shalat dijadikan sebagai perlambang keseluruh ajaran islam. Pelaksanaan shalat melambangkan hubungan seseorang dengan Tuhan, sedangkan pelaksaan zakat melambangkan hubungan antar sesama manusia. 


\section{Landasan Kewajiban Zakat}

Zakat adalah rukun islam ketiga yang diwajibkan dimadinah pada bulan syawal tahun kedua hijriyah setelah diwajibkannya puasa Ramadhan dan zakat Fitrah. Ayat-ayat zakat, shodaqah dan infaq yang turun di makkah baru berupa anjuran dan penyampaiannya menggunakan metodologi pujian bagi yang melaksanakannya dan cacian atau teguran bagi yang meninggalkannya.

\section{Konsep Akuntansi Zakat}

Standar akuntansi tersebut menjadi kunci sukses lembaga pengelolaan zakat dalam melayani masyarakat disekitar sehingga seperti lazimnya harus dapat menyajikan informasi yang cukup, dapat dipercaya, dan relevan bagi para penggunanya, namun tetap dalam konteks syariah islam. akuntabilitas organisasi pengelolaan zakat ditunjukkan dengan laporan keuangan serta audit tehadap laporan keuangan tersebut. Untuk bisa disahkan sebagai organisasi resmi, lembaga zakat harus menggunkan sistem pembukuan yang benar dan siap diaudit akuntan publik. Ini artinya standar akuntansi zakat mutlak diperlukan.

\section{Tujuan Laporan Keuangan}

Menurut Ikatan Akuntan Indonesia (2009 : 45.2) tujuan utama laporankeuangan adalah menyediakan informasi yamg relevan untuk memenuhikepentingan para penyumbang, anggota organisasi, kerditur, dan pihak lain yangmenyediakan sumber daya bagi organisasi nirlaba.Secara rinci, tujuan laporan keuangan, termasuk catatan atas laporankeuangan, adalah untuk menyajikan informasi mengenai :

a. Jumlah dan sifat aktiva, kewajiban dan aktiva bersih suatu organisasi;

b. Pengaruh transaksi, peristiwa dan situasi lainnya yang mengubah nilai dansifat aktiva bersih;

c. Jenis dan jumlah arus masuk dan arus keluar sumberdaya dalam satuperiode dan hubungan antara keduanya;

d. Cara suatu organisasi mendapatkan dan membelanjakan kas, memperolehpinjaman dan melunasi pinjaman, factor lainnya berpengaruh pada likuiditas.

Setiap laporan keuangan menyediakan informasi yang berbeda, daninformasi dalam keuangan lain.

\section{METODE PENELITIAN}

\section{Jenis Penelitian}

Penelitian ini merupakan jenis penelitian exploratory, survey dan actionresearch yang dilaksanakan di wilayah Kab.Jember dengan menggunakan triangulation method.

\section{Analisis Data}

Dalam penelitian ini digunakan analisa deskriptif dan komparatif yaitu metode yang dilakukan dengan cara mengumpulkan, mempersiapkan, serta menganalisis data sehingga mendapat gambaran yang jelas mengenai masalah yang diteliti dan menganalisis data dimulai dengan mengumpulkan data primer yang diperoleh dengan metode wawancara terhadap pihak terkait kemudian dikembangkan dan dianalisis berdasarkan data sekunder yang berupa laporan keuangan. Analisis tersebut akan 
memberikan gambaran mengenai standar penerapan akuntansi yayasan yang digunakan yaitu mengenai pengakuan, pengukuran, pengungkapan dan pelaporan.Hasil dari analisa tersebut selanjutnya dibandingkan dengan teori-teori yang diperoleh dari literatur yang mendukung. Tujuan dari analisa ini adalah untuk mengetahui perlakuan akuntansi zakat pada Lembaga amil zakat BMH.

Rancangan kegiatan yang akan dilakukan pada saat observasi antara lain:

1. Pengumpulan data perusahaan.

2. Menganalisis setiap biaya-biaya pengolahan limbah

3. Mengidentifikasi pengakuan, pengukuran, penyajian, dan pengungkapan biaya-biaya yang berkaitan dengan pengolahan limbah

4. Menarik kesimpulan.

\section{HASIL DAN PEMBAHASAN}

\section{Hasil Penelitian \\ Proses Pengumpulan Dana Zakat Oleh Baitul Maal Hidayatullah Cabang Jember}

Sesuai dengan tugas pokok lembaga amil zakat yaitu mengumpulkan, mendistribusikan dan mendayagunakan sesuai dengan ketentuan agama. Maka peranan akuntansi sangat berkaitan dengan proses pengumpulan, pendistribusian, pendayagunaan serta pembuatan laporan keuangan oleh lembaga amil zakat itu sendiri dengan tujuan untuk mempertanggungjawabkan kinerja kepada masyarakat umum, khususnya kepada para muzakki yang telah mempercayakan lembaga amil zakat dalam mengelola yang disalurkan. Berdasarkan pasal 12 ayat 1 No.38 tahun 1999 mengenai pengumpulan zakat, dikatakan bahwa pengumpulan zakat dilakukan oleh lembaga amil zakat dengan cara menerima atau mengambil dari muzakki atas dasar pemberitahuan muzakki, sedangkan pada ayat 2 masih dipasal yang sama dinyatakan bahwa LAZ dapat bekerja sama dengan bank dalam proses pengumpulan zakat harta muzakki di bank atas permintaan muzakki.

Pola pengumpulan dana zakat, infaq, dan shadaqoh yang dilakukan oleh $\mathrm{BMH}$ cabang jember melalui beberapa program, yaitu:

a. Layanan langsung dikantor BMH cabang jember. para donatur atau muzakki yang mempunyai waktu luang dapat menyetorkan langsung dana zakat, infaq, dan shadaqoh di kantor BMH cabang jember.

b. Layanan jemput zakat. Layanan ini diperuntukkan bagi para donatur yang meminta untuk dijemput dana zakat, infaq, dan shadaqoh dirumah, kantor ataupun lokasi yang ditentukan oleh donatur muzakki.

c. Layanan sms dan internet banking. Para donatur dapat membayar zakat, infaq, dan shadaqohnya melalui sms serta transfer yang bekerja sama dengan bankdepartemen sosial republik indonesia.

\section{Pendistribusian Dana Zakat, Infaq, Dan Shadaqoh oleh BMH cabang Jember}

Pendistribusian zakat haruslah dilakukan pada pihak yang berhak menerima zakat, yaitu 8 golongan asnaf. BMH cabang jember sudah memenuhi kewajiban pendistribusian hasil pengumpulan zakat dengan menyalurkan zakat tersebut sesuai dengan kriteria syariah tersebut. 
Pendistribusian dana zakat, infaq, dan shadaqoh pada BMH cabang jember dilakukan dengan membagi penggunaan dana menjadi 2 bagian:

1. Pada pesantren

Pendistribusian yang dilakukan BMH cabang jember kepada pesantren berupa mendirikan pesantren-pesantren dan memberikan sumbangan berupa kebutuhankebutuhan para santri.

2. Pendistibusian kepada para muallaf

Selain kepada pesantren BMH juga mendistribusikan dana zakat kepada para muallaf guna untuk membina dan mengajari para muallaf dari suku pedalaman dan masyarakat sekitar, serta mengadakan program konversi ternak untuk meningkatkan taraf hidup masyarakat.

\section{Pembahasan}

\section{Pengungkapan laporan keuangan pada BMH cabang Jember}

Layaknya perusahaan-perusahaan nirlaba lainnya, dalam melakukan aktivitasnya sebagai lembaga amil zakat, BMH tidak terlepas dari proses pencatat setiap transaksinya. Hal tersebut dikarenakan dana yang dikumpulkan oleh lembaga ini bukan merupakan milik lembaga amil $\mathrm{BMH}$, tetapi merupakan dana titipan dari para muzakki atau donatur yang harus disalurkan kepada orang-orang yang berhak menerimnya sesuai dengan aturan syariah yang berlaku. Lembaga amil zakat juga bertanggung jawab untuk melaporkan kinerja dan laporan keuangannya kepada para muzakki dan stakeholder lainnya.

Sesuai dengan tugas pokok lembaga amil zakat yaitu mengumpulkan, mendistribusikan dan mendayagunakan sesuai dengan ketentuan syariah, maka peranan akuntansi sangat berkaitan dengan proses pengumpulan, pendistribusian, dan pendayagunaan serta pembuatan laporan keuangan oleh lembaga amil zakat itu sendiri dengan tujuan untuk mempertanggungjawabkan kinerjanya kepada masyarakat umum, khususnya para muzakki yang telah mempercayakan ziswafnya kepada lembaga zakat.

Proses pencatatn siklus akuntansi BMH cabang jember memulai transaksi dengan mengumpulkan bukti penerimaan atau bukti pembayaran berupa kwitansi, kemudian dicatat dijurnal dibuku kas perolehan harian dan buku kas distribusi harian, lalu direkap dan dibuat laporan keuangan tahunan.

Manajemen lembaga zakat secara berkala harus menerbitkan laporan keuangannya ini, laporan ini menjadi sangat penting dalam rangka meningkatkan kepercayaan calon muzakki. Keyakinan mereka terhadap lembaga zakat dapat dibangun melalui laporan keuangan yang benar. Laporan keuangan yang dibuat oleh lembaga haruslah sesuai dengan prinsip akuntansi yang berlaku umum, yaitu sesuai dengan prinsip akuntansi dalam hal pengakuan, pengukuran, pengungkapan dan penyajian.

1. Pengakuan

Pengakuan merupakan proses pembentukan suatu pos yang memenuhi suatu devinisi elemen laporan keuangan serta kriteria pengakuan. Pengakuan dilakukan dengan menyatakan pos tersebut baik dalam kata-kata maupun dalam jurnal rupiah tertentu dan mencantumkan dalam neraca. Pengakuan menjelaskan pencatatan elemen-elemen dasar dari suatu laporan keuangan, termasuk didalamnya penjelasan tentang waktu, pengakuan keuntungan atau kerugian organisasi.

\section{Pengukuran}

Pengukuran adalah proses penentuan jumlah uang untuk mengakui dan memasukkan setiap unsur laporan keuangan kedalam laporan posisi keuangan maupun laporan sumber dan penggunaan dana. 
Umumnya Ziswaf yang diterima oleh BMH berbentuk kas dan diukur sejumlah ziswaf yang diterima.

3. Pengungkapan dan penyajian

Pengungkapan berarti bahwa laporan keuangan harus memberikan informasi dan penjelasan yang cukup mengenai hasil aktivitas suatu unit usaha (Anis Chairil, Imam Ghozali, 2003). Dengan demikian LAZ harus menyajikan informasi yang jelas, lengkap dan menggambarkan secara tepat mengenai kejadian ekonomi yang mempengaruhi posisi keuangan LAZ. Tujuan pengungkapan laporan keuangan adalah untuk memberikan laporan kepada pihak eksternal. Pengungkapan ini akan bermanfaat dalam mengevaluasi prestasi (performence) organisasi dalam satu periode, serta menggambarkan pertanggungjawaban LAZ dalam mengelola sumberdayanya dan prestasi kinerja yang telah dihasilkan selama periode tertentu. Pengungkapan yang dikemukakan dalam laporan keuangan di lembaga zakat adalah catatan atas laporan keuangan. Laporan ini berisi penjelasan yang dilampirkan bersama-sama dengan laporan keuangan. Dalam catatan ini dijelaskan mengenai kebijakan-kebijakan akuntansi dan prosedur yang ditetapkan dalam manajemen amil sehingga memperoleh angka-angka dalam laporan keuangan tersebut.

Penyajian lporan keuangan yang dibuat oleh $\mathrm{BMH}$ cabang Jember sebagai lembaga amil zakat adalah sebagai berikut:

\section{Neraca}

Laporan ini berisi posisi keuangan BMH cabang Jember yang menckup nilai aktiva dan passiva. Aktiva terdiri dari atas aktiva lancar, kas dan banh, piutang dan biaya dibayar dimuka, dan aktiva tetap (peralatan), sedangkan passiva terdiri dari kewajiban( kewajiban lancar) dan ekuitas (saldo dana).

Tujuan disusunnya neraca ini adalah untuk menyediakan informasi posisi keuangan yang meliputi penilaian kemampuan organisasi dalam memberikan jasa dan untuk menilai likuiditas, fleksibilitas keuangan dan kemampuannya memenuhi kewajiban dan kebutuhan pendanaan eksternalnya sebagai lembaga yang menjembatani antara muzakki dan mustahiq.

BMH cabang jember sudah membuat laporan posisi keuangan (neraca) sesuai dengan periodenya, dan bentuk pelaporannya sudah sesuai dengan yang ditentukan oleh PSAK 109.

\section{Laporan Arus Kas}

Laporan arus kas merupakan laporan yang menggambarkan jumlah kas masuk dan kas keluar pada satu periode tertentu. Laporan arus kas dapat diklasifikasikan menjadi 3 bagian, yaitu:

a. Arus Kas dari aktivitas operasi

Menggambarkan arus kas masuk dan keluar dari aktivitas utama organisasi. Laporan ini merupakan indikator yang menentukan apakah operasi LAZ menghasilkan arus kas yang cukup untuk memelihara kemampuan organisasi tanpa harus mengandalkan pendanaan dari luar. Contoh arus kas utama operasi antara lain: penerimaan dari zakat, infaq dan shadaqoh serta sumber lainnya. Sedangkan pengeluaran kas digunakan untuk fakir miskin, kaum dhuafa, dan belanja organisasi dan personalia (amil), dan lain-lain.

b. Arus kas dari aktivitas investasi

Laporan ini menggambarkan arus kas masuk dan kas keluar sehubungan dengan sumber daya organisasi yang bertujuan untuk menghasilkan pendapatan dan arus kas masa depan, contohnya: pembayaran kas untuk pembelian akiva tetap, 
pengeluaran kas untuk penanaman investasi pada perusahaan lain, penerimaan kas dari penjualan aktiva tetap, penerimaan kas dari bagi hasil investasi maupun simpanan.

c. Arus kas dari aktivitas pendanaan

Laporan ini menggambarkan arus kas yang masuk dan keluar dari sumber pendanaan jangka panjang, seperti penerimaan kas dari pembiayaan jangka panjang serta pembayaran angsurannya.

Sejauh ini BMH cabang jember sudah membuat laporan arus kas yang sudah ditentukan di standart PSAK 109.

3. Catatan atas laporan keuangan

Laporan ini berisi tentang rincian aktivitas LAZ yag berfungsi memberikan penjelasan tentang laporan keuangan. Laporan ini dapat berwujud kualitatif maupn kuantitatif. Dalam hal ini BMH cabang jember sudah membuatbuatnya.

Berdasarkan uraian diatas, dapat disimpulkan bahwa BMH cabang jember mengenai pedoman dalam membuat laporan keuangan sudah mengacu pada pedoman dan standart yang sudah ditentukan di PSAK 109.

\section{Perbandingan laporan keuangan BMH cabang Jember dengan standar PSAK 109}

Komponen laporan Keuangan yang lengkap lembaga amil zakat menurut PSAK 109 terdiri atas :

1. Neraca (Laporan Posisi Keuangan)

2. Laporan Perubahan Dana

3. Laporan arus kas

4. Catatan atas laporan keuangan

\section{Kesimpulan}

\section{KESIMPULAN}

Berdasarkan dari hasil penelitian yang telah dibahas dalam bab sebelumnya, dihasilkan beberapa simpulan berikut, antara lain:

1. Pengakuan akuntansi terhadap dana zakat yang dilakukan oleh BMH cabang jember dilakukan berdasarkan nilai dasar tunai (cash basis) dimana pencatatan dilakukan pada saat kas diterima dan pada saat kas dikeluarkan. Pengukuran dana zakat yang dikumpulkan oleh BMH cabang Jember didasarkan atas ketentuan syariah yang mengatur mengenai perhitungan nishab zakat. Pengungkapan dilakukan dalam catatan atas laporan keuangan yang menjelaskan mengenai kebijakan akuntansi dan prosedur yang ditetapkan manajemen $\mathrm{BMH}$ sehingga memperoleh angka-angka dalam laporan keuangan. Pada prinsipnya BMH cabang jember telah menerapkan akuntansi PSAK 109, namun dalam penyajian laporannya masih kurang persis dengan laporan yang di tentukan di PSAK 109.

2. Laporan keuangan BMH cabang jember sudah diaudit oleh auditor internal sebagaimana tertuang dalam ketetapan KMA No. 581 tahun 1999. Dimana jika BAZ sudah diaudit oleh auditor independen ataupun kantor akuntan publik maka akan memberikan nilai tambah bagi transparansi serta akuntabilitas terhadap laporan 
keuangan yang dibuatnya sehingga akan meningkatkan kepercayaan masyarakat terhadap BAZ untuk mengelola zakat, mendistribusikan dan mendayagunakan.

\section{Saran} berikut:

Berdasarkan keterbatasan penelitian, maka dapat disarankan hal-hal sebagai

1. Diharapkan penelitian selanjutnya bisa mengambil objek penelitian yang lebih luas dan lebih banyak karena dalam penelitian ini hanya mengambil satu objek penelitian. Alangkah lebih baik jika objek penelitian lebih dari satu sehingga bisa dikomparasi dengan lebih variatif. Serta tidak menutup kemungkinan jika IAI sudah mengesahkan PSAK 109 selain mengkomparasi laporan keuangan penelitti juga bisa menganalisis kepatuhan lembaga amil terhadap PSAK 109.

2. Dalam melakukan penelitian selanjutnya diharapkan lebih lama dan menggunakan waktu seefektif dan seefisien mungkin agar bisa memahami dan lebih tahu mengenai siklus akuntansinya sampai proses pembuatan laporan keuangan.

3. Pelaporan keuangan BMH selama ini telah berjalan sesuai dengan PSAK 109 diharapkan dapat dipertahankan serta pencatatan dan penyajian laporan keuangan yang belum sesuai diharapkan memiliki targetan perapian dalam pencatatan dan penyajian sehingga terealisasi perapian pelaporan keuangan yang sesuai dengan PSAK 109 karena pengarsipan dokumen-dokumen yang diperlukan dalam penyusunan pencatatan dan penyajian dana zakat selama ini sudah rapi.

\section{DAFTAR PUSTAKA}

Ali, Nuruddin, Zakat Sebagai Instrumen Kebijakan Fiskal, Jakarta: PT. Raja Grafindo Persada, 2006.

Al-Zuhayly, Wahbah, Zakat Kajian Berbagai Mazhab, Cet. 6, Bandung: PT. Remaja Rosdyakarya, 2005.

An-Nabahan, M. Faruq, Sistem Ekonomi Islam, Cet. 3, Yogyakarta: UII Press, 2002.

Sistem Ekonomi Islam: Pilihan Setelah Kegagalan Sistem Kapitalis dan Sosialis, Cet. 3, Yogyakarta: UII Press, 2002.

Arikunto, Suharsimi, Prosedur Penelitian Suatu Pendekatan Praktek, Jakarta: Rineka Cipta, 2002.

Prosedur Penelitian, Jakarta: Rineka Cipta, 1998.

Ash-Shiddieqy, M. Hashbi, Pedoman Zakat, Semarang: PT. Pustaka Rizki Putra, 2002.

Azizy, A. Qodri, Membangun Fondasi Ekonomi Umat, Yogyakarta: Pustaka Pelajar, 2004.

Azwar, Safidin, Metodologi Penelitian, Yogyakarta: Pustaka Pelajar, 1998.

Danim, Sudarwan, Menjadi Peneliti Kualitatif, Bandung: CV Pustaka Setia, 2002.

Hafidhuddin, Didin, Zakat Dalam Perekonomian Modern, Jakarta: Gema Insani Press, 2002. 
, Zakat Infaq Sedekah, Cet. 7, Jakarta: Gema Insani, 2008.

2002.

Zakat Dalam Perekonomian Modern, Cet.1, Jakarta: Gema Insani,

M. Mufraini, Akuntansi Dan Manajemen Zakat, Jakarta: Kencana Prenada Media Group, 2006.

Mas'udi, Masdar Farid, dkk., Reinterprestasi Pendayagunaan ZIS Menuju Efektivitas Pemanfaatan Zakat Infaq Sedekah, Jakarta: Piramedia, 2004.

Pajak Itu Zakat: Uang Allah Untuk Kemaslahatan Rakyat, Bandung: PT. Mizan Pustaka, 2005.

Moleong, Lexy J., Metodologi Penelitian Kualitatif, Cet. X, Bandung: Remaja Rosdakarya, 2005.

Mufraini, M. Arif, Akuntansi dan Manajemen Zakat, Jakarta: Prenada Media Group, 2006.

Mursyidi, Akuntansi dan Zakat Kontemporer, Bandung: PT. Remaja Rosdyakarya, 2006.

Nasution, Edwin Mustofa, Pengenalan Eksklusif: Ekonomi Islam, Jakarta: Kencana Prenada Media Group, 2006.

Prodjosiswoyo, R. Kadlan-Imam Musa, Kitab Hadits Pegangan Maulana Muhammad Ali, Jakarta: CV Kuning Mas, 1992.

Qadir, Abdurrachman, Zakat dalam Dimensi Mahdhah dan Sosial, Cet. 2, Jakarta: PT. Raja Grafindo Persada, 2001.

Qardawi, Yusuf, Hukum Zakat, Cet. 10, Jakarta: PT. Mitra Kerjaya Indonesia, 2007.

Rahman, Afzalur, Doktrin Ekonomi Islam Jilid III, Yogjakarta: PT. Dana Bhakti Wakaf, 1996.

Ridwan, Muhammad, Manajemen Baitul Maal Wa Tamwil, Yogyakarta: UII Press, 2004.

Rofiq, Ahmad, Fiqh Kontekstual Dari Normatif Ke Pemaknaan Sosial, Semarang: Pustaka Pelajar, 2004.

Soemitra, Andri, Bank \& Lembaga Keuangan Syari'ah, Jakarta: Kencana Prenada Media Group, 2009.

Usman, Suparman, Hukum Islam (Asas dan Pengantar Studi Hukum Islam dalam Tata Hukum Indonesia), Cet. 2, Jakarta: Gaya Media Pratama, 2002.

Yasyin, Sulchan, /2011/01/sejarah-pkpu-20.html 